\title{
Mikołaj Madurowicz
}

Wydział Geografii i Studiów Regionalnych

Uniwersytet Warszawski

\section{Zmysłowo-obyczajowa urbanistyka u powojennych poetów piosenki (Jeremi Przybora, Agnieszka Osiecka, Wojciech Młynarski)}

Geografia, kartografia, mapa, plan, region... są pojęciami, które - jako dookreślenia i przydawki znalazłszy się poza kontekstem nauk o przestrzeni i przestrzenności - znamiennie metaforyzują się i synekdochizują, służąc niczym tropy interpretacyjne chociażby w antropologii, kulturoznawstwie czy literaturoznawstwie. Na tej transpozycji owocnie zyskać może zarówno ten, kto widzi w mapie próbę odwzorowania przestrzeni realnej, dysponując na podorędziu siatką kartograficzną, podziałką, legendą, jak i ten, kto traktuje mapę jako zapis ludzkiego doświadczenia. I w jednym, i w drugim przypadku perspektywę funduje umowność. W takim duchu rozważyć chciejmy dziedzinę urbanistyki. Ta ostatnia, klasycznie rozumiana, jest „nauką o budowie miast i osiedli oraz o problemach dotyczących urządzania i zorganizowania pod względem technicznym, gospodarczym i kulturowym" ${ }^{11}$, tak więc poza zakładaną implicite systemowością myślenia, niezbędna okazuje się dla urbanisty znajomość fizycznych parametrów miejsca, a w nim ludzkich działań, jak również idei i pojęć je określających. Jeszcze krok - i znaleźlibyśmy się w przestrzeni społecznej kanonicznie definiowanej przez Aleksandra Wallisa. Ale przystańmy, aby spojrzeć nieco inaczej.

Otóż, zmysłowo-obyczajowa urbanistyka byłaby metaforą właśnie spojrzenia na rzeczywistość miejską pod kątem zmysłowości i obyczajowości, tudzież próbą uczuciowo-emocjonalnego zagospodarowania miasta jako do-

1 J.M. Chmielewski, Teoria urbanistyki w projektowaniu i planowaniu miast, Warszawa 2001, s. 9. 
meny interpretacji i doświadczenia, obecności/nieobecności i znaczenia oraz pamięci (nostalgii, tęsknoty). Rolę architekta, urbanisty, planisty i obserwatora podejmie $\mathrm{w}$ takiej sytuacji humanista (np. pisarz, poeta, eseista), a jego znajomość fizycznych parametrów miejsca pozostaje na drugim planie wobec świadomości ludzkich działań w danym miejscu, a także pojęć i idei je określających. Podstawową kategorią operacyjną jest zatem miejsce (zamiast przestrzeni, środowiska, regionu), wykładnikiem - jakość (zamiast ilości, częstotliwości), kontekstem zaś użytecznym - metafora (zamiast algorytmu). Wśród aspektów badawczych adekwatnych do takiego rozumienia urbanistyki moglibyśmy włączyć następujące: miasto przywoływane sygnalnie (ze względów treściowych - dla ukonkretnienia dyskursu bądź formalnych - np. rytmicznych), miasto jako entourage, kanwa przestrzenna narracji (te dwa aspekty poza marginalnymi wzmiankami na początku pominiemy), obyczajowość miejska, miejska przestrzeń zmysłów, emocji i uczuć, ślady/świadectwa miejskiego autentyzmu, miasto jako metafora, miejskie diagnozy i konstatacje, miejskie przestrzenie wyobraźni, wreszcie - miejskie idiomy.

Jeremi Przybora, Agnieszka Osiecka, Wojciech Młynarski - wspaniali poeci piosenki, mistrzowie mowy wiązanej, zapadających $\mathrm{w}$ pamięć bezbłędnych warsztatowo fraz i celnych point, nęcących szlagwortów i sformułowań od razu wchodzących do języka - w swej twórczości zdradzili się jako zmysłowo-obyczajowi urbaniści, którzy miejską scenką rodzajową, anegdotą urastającą niekiedy do rangi paraboli ludzkiego losu, gorzkim lub dowcipnym spostrzeżeniem bądź trafnym portretem zaludniają i meblują nasz zurbanizowany świat, przyczyniając się do jego wzbogacenia (czemu ochoczo przyklasnąłby Władimir Toporow, rad z takiego tekstu miasta). Współtwórca Kabaretu Starszych Panów wśród dobrych kilkuset utworów ofiarował nam 45 miejskich perełek, piewczyni warszawskiej Saskiej Kępy na niemal półtora tysiąca piosenek miastu poświęciła 126 niezapomnianych obrazów, natomiast nieustannie wciąż „robiący swoje” między tysiącem tekstów śpiewanych przyjrzał się przestrzeni miasta aż 95 razy. Nie o ilość atoli nam chodzi, lecz o wyrazistość tych szkiców, nierzadko pogłębiających semantycznie rzeczywistość, utrwalających lokalne historie i obyczaje zaułków metropolii, barwiących anonimowe miejsca w eliksirze nazw i imion. „Tu bywała Zosia Czacka”2, "tam zajeżdża tramwaj nadziei niewinnej i na

2 J. Przybora, Przeprowadzka, w: tegoż, Piosenki prawie wszystkie, Warszawa 2001 (dalej jako PPW), s. 339; dla innych dzieł Przybory, cytowanych w niniejszym opracowaniu, stosuję następujące skróty: KSP2 - Kabaret Starszych Panów. Wybór drugi, Warszawa 1973; MF - Mieszanka firmowa, Warszawa 1977; PKŚ - Piosenki, które śpiewali inni, Wrocław 1991. 
ten tramwaj ktoś czeka" ${ }^{3}$, "stare, dobre, kochane adresy" 4 - oto imienna topografia, odruchowa orientacja przestrzenna, dowód osobisty miasta i jego mieszkańców. Nie o liczbę wspomnianych miast idzie gra, bo cóż nam po wiedzy, że Przybora odwiedził frazą poetycką 26 miejscowości, Osiecka podróżowała słowem do 96, a Młynarski - piosenkowo napomknął o 59. Niewykluczone, że ważniejszą informacją jest to, iż najczęściej lokalizowali swoją wyobraźnię artystyczną nade wszystko w Warszawie, potem zaś w Paryżu i Krakowie, dla Kutna, Wołomina, Łomży i Nakła rezerwując osobne miejsce.

Niemniej jednak nie przybliża nas taka pobieżna statystyka do istoty niniejszych rozważań. Toteż nie wsłuchując się na razie w utwory, w których miasto przywołano sygnalnie, ani w takie, gdzie miasto stanowi li tylko kanwę przestrzenną narracji, skoncentrujmy się na miejskiej twórczości trojga poetów piosenki zabierającej nas na siedem kluczowych spacerów, a mianowicie: 1) śladem miejskiej obyczajowości, 2) śladem miejskich zmysłów, uczuć i emocji, 3) śladem autentyzmu, 4) w poszukiwaniu miasta jako metafory, 5) tropem miejskich diagnoz i konstatacji, 6) w stronę przestrzeni wyobraźni oraz 7) szlakiem miejskich idiomów. Wyekwipowani badawczo w dodatkowe klucze interpretacyjne ruszajmy do krainy miejskich pragnień i potrzeb.

Zanim podejmiemy peregrynacje wypada wspomnieć o dwóch kwestiach. Po pierwsze o tym, że asumpt intelektualny do aranżacji spodziewanej miejskiej przestrzeni znaczącej dał m.in. Yi-Fu Tuan ${ }^{5}$ wykładnią miej-

3 A. Osiecka, Tramwajowi ludzie, w: tejże, Sentymenty, Torun 1996 (dalej jako S), s. 87; dla innych dzieł Osieckiej, cytowanych w niniejszym opracowaniu, stosuję następujące skróty: NW - Najpiękniejsze wiersze i piosenki, Warszawa 2010; WŚ - Wielki Śpiewnik Agnieszki Osieckiej, t. 1, Warszawa-Kraków 2004; Wielki Śpiewnik Agnieszki Osieckiej, t. 2: STS i nie tylko, Warszawa-Kraków 2005; Wielki Śpiewnik Agnieszki Osieckiej, t. 3: Apetyt na życie, Warszawa-Kraków 2005; Wielki Śpiewnik Agnieszki Osieckiej, t. 4: Strofki o miłości, Warszawa-Kraków 2006; Wielki Śpiewnik Agnieszki Osieckiej, t. 6: Rock and roll, Warszawa-Kraków 2006; Wielki Śpiewnik Agnieszki Osieckiej, t. 8: Małgośka, Warszawa-Kraków 2007; Wielki Śpiewnik Agnieszki Osieckiej, t. 9: Zielono mi, Warszawa-Kraków 2008; Wielki Śpiewnik Agnieszki Osieckiej, t. 10: Dawne zabawne, Warszawa-Kraków 2009 (wszystkie tomy śpiewnika w opracowaniu A. Passent i J. Borkowskiego); L - Agnieszki Osieckiej i Jeremiego Przybory listy na wyczerpanym papierze, oprac. M. Umer, Warszawa 2010.

4 W. Młynarski, Nie ma gdzie pójść, w: tegoż, Róbmy swoje, Warszawa 1985 (dalej jako RS), s. 82; dla innych dzieł Młynarskiego, cytowanych w niniejszym opracowaniu, stosuję następujące skróty: JWZ - Jeszcze w zielone gramy, Wrocław 1988; PM - Polska miłość, Warszawa 1992; WCB - W co się bawić?, Kraków 1993; MPIP - Miłe Panie i Panowie bardzo mili, Warszawa 1995; RoS - Robię swoje, Warszawa 1999; MUD - Moje ulubione drzewo, czyli Młynarski obowiązkowo, Kraków 2007.

5 Y.-F. Tuan, Przestrzeń i miejsce, przeł. A. Morawińska, Warszawa 1987. 
sca (jako obrazu ludzkich uczuć i odbicia jakości ludzkich zmysłów), wzór konstruowania i lektury tekstu miasta podpowiedział Władimir Toporow ${ }^{6}$, który to tekst możemy odczytywać i wymazywać, jak proponuje Ewa Rewers $^{7}$ w ramach ontologii śladów i pustek (obecności/nieobecności), bądź też interpretować (podług właściwości emotywnych, alegorycznych, symbolicznych), co z kolei sugeruje Henryk Markiewicz ${ }^{8}$. Zaiste, janusowe oblicze miasta jako punktu na mapie/planie (w ujęciu uniwersalistyczno-obiektywistycznym) oraz jako fragmentu ludzkiego doświadczenia (w ujęciu sytuacyjno-subiektywnym ${ }^{9}$ ) staje się zbawiennym uwarunkowaniem wszelkich dociekań utrzymanych $\mathrm{w}$ nurcie badań z zakresu chociażby geobiografii, geopoetyki czy geografii humanistycznej. Po drugie zaś, należy nadmienić o dotychczasowych bezcennych studiach poświęconych artystycznemu, naukowemu i popularnemu dorobkowi poetycko-piosenkowemu Wielkich Tekściarzy ${ }^{10}$. Nawiasem mówiąc, a przywołajmy tutaj opinię Młynarskiego, na nobilitujące w dziedzinie twórczości scenicznej, w świecie słowa śpiewanego miano „tekściarza" długo się pracuje i trzeba na nie zasłużyć. Zmysłowo-obyczajowy urbanista nie przymierza bynajmniej maski inżyniera ludzkich dusz czy sumien; to opowiadacz przestrzeni nieobojętnej.

\section{Spacer 1. Śladem miejskiej obyczajowości}

Konturowy plan miejskiego savoir-vivre'u, ową treściwą narrację spacjalną ukonstytuują $\mathrm{z}$ jednej strony ludzie, z drugiej - miejsca, następnie relacje ich wzajemne $\mathrm{w}$ pewnych okolicznościach. Kim są wobec tego protagoniści? Kogo możemy spotkać, z kim się zaprzyjaźnić, a kogo lepiej unikać? Od kogo i czego możemy się nauczyć? Jakie miejsca omijać, a gdzie bezszelestnie (bo tak bezpieczniej, a niewykluczone, że po prostu bardziej elegancko) podjąć wysiłek dopasowania się do lokalnego kontekstu?

Wystarczy rzut oka Starszego Pana na „złą dzielnicę szumiącą niepokojem”, dokąd co nocy zmierza pod okno ukochanej "przybłęda z dzielnic sy-

6 W. Toporow, Miasto i mit, przeł. B. Żyłko, Gdańsk 2000.

7 E. Rewers, Post-polis. Wstęp do filozofii ponowoczesnego miasta, Kraków 2005.

8 H. Markiewicz, Wymiary dzieła literackiego, Kraków 1996.

9 Por. E. Rewers, Post-polis, s. 167.

10 Zob. m.in. P. Derlatka, Poeci piosenki 1956-1989. Agnieszka Osiecka, Jeremi Przybora, Wojciech Młynarski, Jonasz Kofta, Poznań 2012; R. Dziewoński, Kabaretu Starszych Panów wespót w zespót, Warszawa 2002; R. Dziewoński, M. i G. Wasowscy, Ostatni naiwni. Leksykon Kabaretu Starszych Panów, Warszawa 2005; I. Kiec, Wyprzedaż teatru w ręce błazna i arlekina... czyli o kabarecie, Poznań 2001; D. Michalski, Dookoła Wojtek. Opowieść o Wojciechu Młynarskim, Warszawa 2008. 
tych bourgeois", kędy "krążą oprychy”, „pijacy klną”, a "gościa pod pachę prowadzi dziwka”. Sznytu wielkomiejskiej grozy dopełnia, a jakże, pointa: „pod twoim oknem nożem dostanę i wcale serca nie będę krył"11. Jeremi Przybora uszlachetnia pejzaż ciemnej strony miasta lekko uniewinniającą przenośnią: „o ty, Koryncie sławny! W tobie rodzinnym mieście wabią twe kurtyzany jak twe rodzynki w cieście", aliści również zatroskanym ostrzeżeniem, że nawet tam, gdzie „Z radia płynął walczyk"12 Vincente Osculati, bałamutny Portugalczyk „wykorzystuje ze szczętem”. W ramach obserwacji porównawczych między kulturami konstatujemy ze zgorszeniem i współczuciem, że - inaczej niż przyzwoity tubylec - „nie uiścił”, „nie dofinansował”. Idąc w takim razie "cienistą stroną ulicy", gwoli uniknięcia rozczarowań bądź namacalnej bezceremonialności, wypatrujmy „rojnych kawiarni”, miejsc, gdzie „tłumek się garnie” (np. wokół niemych kin). Zresztą motyw "tłoczku przed kinem" antypodalnie ewokuje od razu „uśpione uliczki”, odludne zieleńce (,w tym parku-śmy sami"13), podobnie jak archetypicznie kontrastują sfera profanum („na rynku zawsze ludniej, gdy targ przy starej studni”) i sacrum, potraktowana z lekkim przymrużeniem dobrotliwego oka („,u wrót plebanii drzemie dziad") ${ }^{14}$. Zasadą regulującą życie i rytm miasta u Przybory jest bowiem uśmiechnięta życzliwość. Chociaż w średnich miastach „mężczyzna czy niewiasta nie zwykli są sąsiadów swych przerastać", to przecie stać ich na przezorną egzaltację („,z jedną myślą przebiegasz ulice: gdyby wdówkę tak ciepłą napotkać”), odrobinę szaleństwa („,szło się ślizgać na Dynasy"), może nieco utopijną wyrozumiałość („i darzą uśmiechem się wzajem, i wszyscy do czysta wymyci"), tudzież obywatelską współodpowiedzialność („deptanie trawników to hańba trzewików”) ${ }^{15}$. Obyczajowość intymniejsza wije gniazda w kawiarence, dajmy na to „Sułtan”, jeśli bardziej śmiała, albo - jeśli płochliwa - w izdebkach („twego domu próg na Hożej”) lub facjatkach, ale donośnie - jeśli z kolei sytuacja się dynamizuje (np. na Złotej „że aż huczy pianino - na cztery ręce co dzień gram z Moniką mą" ${ }^{16}$. Aż szczery żal wzbiera, iż ustawy o planowaniu i zagospodarowaniu przestrzennym nie dyktował Jeremi Przybora.

\footnotetext{
11 J. Przybora, Pod twoim oknem co nocy stoje, PPW, s. 80-81.

12 Kolejno cyt. za: J. Przybora, Koryntu my cór chór, PKŚ, s. 197; tegoż, Portugalczyk Osculati, MF, s. 269.

13 J. Przybora, Zimowy duet, PPW, s. 34.

14 J. Przybora, Stacyjka Zdrój, KSP2, s. 141.

15 Kolejno cyt. za: J. Przybora, Średnie miasta, PPW, s. 413; tegoż, Ciepta wdówka na zimę, PPW, 234; tegoż, Dziadek Paździerzak, PPW, s. 425; tegoż, Już czas na sen, PPW, s. 282; tegoż, Nie deptać trawników!, KSP2, s. 80.

16 Kolejno cyt. za: J. Przybora, To było tak, PPW, s. 119; tegoż, Pani Monika, PPW, s. 102.
} 
Wielki almanach rozedrganej obyczajowości wyczarowała miastu, utrwalając jego ludzkie tęsknoty i przyzwyczajenia, Agnieszka Osiecka. I znowu (za jej podpowiedzią) skierujmy najpierw kroki w podejrzane miejskie ostępy, ot choćby zajrzyjmy na warszawską Chmielną: tam budka z piwem w bramie, burdel, naprawa wiecznych piór, a „obok gnojówki stał cadillac”; „nurt ludzi śpieszących, napisy krzyczące i nieba gdzieś skrawek, i w domyśle - słońce" prowadzą już to na Wolę do dansingu "Dziesięć mandolin”, już to ustawiają w kolejce po "Express", już to ekspediują na Czerniakowską róg Gagarina do knajpy „Sielanka” - gdzie Czarna Mańka, „i jeszcze Gienek, i Gienka kumpel”, gdzie "zakład otwiera fryzjer Ignacy”... A „niech no przyjdą chłopcy z Mokrej" - „takich spotkać na ulicy to jest pech" ${ }^{17}$. Miejskie typy charakterystyczne to nie tylko odrysowane ze swadą sylwetki piekarza, krawca, stróża, kominiarza, dozorczyni, kwiaciarki, ulicznych muzykantów, to także przysłowiowi „,chłopaki z Czerniakowskiej, gołębie z Marszałkowskiej” (niezbywalne elementy krajobrazu) czy „każda pyskata, każda warszawska i nogi aż do ziemi ma", lecz może w głównej mierze ucieleśnione autoidentyfikacje, osobowe znaki rozpoznawcze, pojemne oryginały rodzajowe, typu: banda Rudej Barbary („czy sąd nad Wisłą kiedyś błądził?”) ${ }^{18}$, donkiszot wychodzący na spacer (wśród domków koślawych, praskich ruder), grupki okularników, tramwajowi ludzie, „ci z Kalwarii, ci z Londynu”, ci z manierami "spod Szamotuł” czy „spod Kutna”, przesiadujący „przy małym szkiełku w niedużym piekiełku” ${ }^{19}$, wracający bladzi, bo byli „na konikach" ${ }^{20}$... Oni wszyscy uwiarygodniają przestrzeń miasta, umacniając obyczajowo, behawioralnie definiując - nie marketingowy, lecz prawdziwy - wizerunek, etykietą towarzyską ujędrniając tekst miasta, nawet jeżeli ten blaknie i wdzięcznie oddaje się w pacht melancholii... jak "warszawka z dawnych lat”, jak "lwowskie tango" i „paryski walczyk" (ckliwe to klisze, przyznajmy, a i coraz mniej czytelne), jak podróże tramwajem kochanków z ulicy Kamiennej, co „pierścionków, kwiatów nie dają" ${ }^{21}$. Życie obyczajowe u Osieckiej

17 Kolejno cyt. za: A. Osiecka, Ballada o Chmielnej, WŚ, t. 2, s. 19; tejże, Zmęczyło mnie miasto, NW, s. 600; tejże, Zabawa w "Sielance”, WŚ, t. 2, s. 237; tejże, Księżyc frajer, WŚ, t. 10, s. 102; tejże, Sing, Sing, NW, s. 320.

18 Kolejno cyt. za: A. Osiecka, Nikomu nie żal pięknych kobiet, NW, s. 520; tejże, Panie Kwiatkowski, panie Kowalski, WŚ, t. 9, s. 59; tejże, To wszystko z nudów, WŚ, t. 10, s. 210.

19 A. Osiecka, Siedzę w Mławie, WŚ, t. 4, s. 125.

20 A. Osiecka, Zamiast wódke pić (Skąd ty wracasz taki blady), WŚ, t. 1, s. 171.

21 A. Osiecka, Kochankowie z ulicy Kamiennej, NW, s. 19. Wiele wątpliwości narosło wokół tego adresu; zainteresowani tym wątkiem powinni zajrzeć do Wielkiego Śpiewnika Agnieszki Osieckiej, aby upewnić się, czy interpretacyjna kontrowersja lokalizacyjna łódzko-warszawska pozostaje jedyną... 
odchodzi nieśpiesznie, jakkolwiek nieodwracalnie do lamusa, niekiedy niemalże $\mathrm{z}$ wersu na wers, ze strofki na strofkę. Przemija ta miejska przestrzeń znacząca, a jej uwierzytelniający paszport traci ważność: kto współcześnie chadza na dansingi, pisuje piórem wiecznym, sprzedaje na tandecie?...

Ocalić miejską przaśną (paradoksalnie) belle epoque od zapomnienia próbuje niestrudzenie Wojciech Młynarski, nie wyłącznie $w$ swych śpiewanych felietonach. Skoro od trzewi nieczystych podążanie nasze inicjowaliśmy uprzednio, także i teraz zanurzmy się w szemraną duszę miejską. Okazuje się, że to, co przeczuwali i oswajali Przybora i Osiecka, niczym papierek lakmusowy poniekąd traktuje Młynarski, zauważając trzeźwo: „społeczność mamy, jaką mamy, ale na szczęście jest margines" ${ }^{22}$. Oto paradoksalna ostoja przed demoralizacją powszechną, znijaczeniem, uniwersalizacją oraz swoista szkoła życia, aż korci dopowiedzieć - enklawa przyzwoitości i uczciwości. „Alkoholicy z mojej dzielnicy siedzą na murku jak ptaszki, slangiem najczystszym mówią mi: Mistrzu, zbrakło nam trochi do flaszki...". Jak to określił sam autor w komentarzu do piosenki: „Okolice teatru Ateneum, ulica Dobra, twarze czysto filozoficzne. Działa tam rodzaj klubu dyskusyjnego" ${ }^{23}$. Ot, refleksja zamiast agresji, przez egzystencję do metafizyki. Niby szary, brudny, nieogolony świat, a etyka i estetyka - aż podziw bierze (ma się rozumieć - epistemologiczny). W sepiową poświatę wchodzą u Młynarskiego ,już-za-chwilę-nieobecne” zarówno przedwojenne rytuały i konfiguracje personalne („wuj konkubinę miał w Brwinowie”), bolesne rany krajobrazowe i nie tylko takie („tych miasteczek nie ma już, pokrył niepamięci kurz te uliczki, lisie czapy, kupców rój, płotek z kozą żywicielką, krawca Szmula z brodą wielką, co jak nikt umiał szyć ślubny strój"), jak i powojenne radości, olśnienia i ambicje („Bal Spółdzielców lub działaczy raut”, „na sypkość uczuć i brak przyjaciela - niedziela na Głównym, na Głównym niedziela") ${ }^{24}$. Wędrujemy dzisiaj zwłaszcza po mieście nostalgii i tęsknoty („nie ma gdzie pójść”, ponieważ „stare, dobre, kochane adresy” - „stare Hybrydy”, kabarety "Szpak, „Owca”, „Dudek” - wyretuszowano z planu; a teraz... „są Bristole, są Marriotty, lecz do żartów mniej ochoty i nie bardzo jest gdzie pójść, bo nie ma Dudka"), wałęsamy się po mieście pretensji, bylejakości i wyrzutu („strasznie trudno w Śródmieściu spotkać inteligenta”, „ta Warszawa, fakt widoczny, nabzdyczona jest i tłoczna, lecz prawdziwych

\footnotetext{
22 W. Młynarski, Ludzie marginesu, RoS, s. 60.

23 W. Młynarski, Alkoholicy z mojej dzielnicy, MUD, s. 221.

24 Kolejno cyt. za: W. Młynarski, Truskawki w Milanówku, MUD, s. 155; tegoż, Tak jak malowat pan Chagall, MUD, s. 156; tegoż, Światowe życie, MUD, s. 50; tegoż, Niedziela na Głównym, MUD, s. 55 .
} 
warszawiaków to w niej nie ma") ${ }^{25}$. Żalem (m.in. do obecnych obsługujących w sklepach o brak zaangażowania i kultury osobistej - mimochodem wydobywając z przeszłości wzorzec postawy subiektów od Wokulskiego) i gniewem (m.in. wobec decydentów, którzy zamierzają rozwiązać teatry „,Rozmaitości”, ,Syrena”, „Na Woli”, „Rampa”, „Nowy”) Wojciech Młynarski jak gdyby, fotograficznie rzecz ujmując, w negatywie, w brakujących imponderabiliach i ponderabiliach - poprzez konceptualną wyrzutnię - upatruje esencji miasta, jego tożsamości. Rzadkie wzruszenie rezerwuje dla miejsc specjalnych („naszych matek maleńkie mieszkanka”), natomiast miękkie zatroskanie dla podstawowych relacji międzyludzkich („,ściany między ludźmi, ściany coraz cieńsze”). Zapewne zwrot „rano po bułki w sklepie stać” wydaje się jeśli nie abstrakcją, to prehistorią ${ }^{26}$.

Summa summarum, nicuje przestrzeń miejską trójka poetów piosenki, dokumentując - jak widać - obyczajowy puls przedwczorajszego miasta.

\section{Spacer 2. Śladem miejskich zmysłów, uczuć i emocji}

O ile febliki i newralgie obyczajowe ukazały się jako paradygmatyczna tkanka urbanistycznej narracji, o tyle syntagmatyczną pieczęcią wydają się próby oswojenia i zmiękczenia przestrzeni miasta, dostrzeżenia nieneutralnej opowieści lokalnej, ponieważ wypełnionej jakże potrzebną zmysłowością, ważkimi uczuciami tudzież konkretnymi emocjami. I znowu, jak w przypadku substratu obyczajowego, dzięki nasyconemu jakościowo miejskiemu uniwersum doświadczamy czegoś więcej aniżeli fizycznej kanwy służącej statystycznym i przewidywalnym działaniom, wchodzimy bowiem w Ingardenowski specyficznie ludzki świat.

Wikłamy się przecie w uczuciową amplitudę, której skrajne wychylenia sygnowane są - jak u Jeremiego Przybory - rozczarowaniem („tak bezlitośnie tym zdaniem mnie zranił, że nagle serce uwięzło mi w krtani"), udręczoną miłością („pod twoim oknem nożem dostanę i wcale serca nie będę krył. A potem potknie się o mnie ranek i facet, który u ciebie był"), ukochaną lokalizacją („,u niej na Złotej”, „,twego domu próg na Hożej. Umówiony stuk do wiadomych drzwi, szelest bosych stóp, szum wezbranej krwi") czy miejską apologią stanu oczarowania („,czas pachnieć lipowym alejom [...]

25 Kolejno cyt. za: W. Młynarski, Nie ma gdzie pójść, RS, s. 81-82; tegoż, Dudek, MPIP, s. 82; tegoż, Powrót do Śródmieścia, MUD, s. 167; tegoż, Od dziś w „Expressie”, MPIP, s. 87.

${ }^{26}$ Kolejno cyt. za: W. Młynarski, Naszych matek maleńkie mieszkanka, MUD, s. 168; tegoż, Ściany między ludźmi, PM, s. 19; tegoż, Polska miłość, RS, s. 11. 
tramwaje i kina niepełne [...] na plażach jest szczęście zupełne") 27. Natomiast uczuciowe wahadło Foucaulta, uruchomione wyobraźnią poetycką Agnieszki Osieckiej, osiąga swe kulminacje zrazu również w rozgoryczeniu (,już zapisani byliśmy $\mathrm{w}$ urzędzie, białe koszule na sznurze schły"), aby następnie otrzeć się o tęsknotę („senne wozy jadą z targu, czerwienieje nieba skłon, a ja wciąż z tą samą skargą, co mnie gna do twoich stron”, "lecz wyjechałeś z Portofino... na drodze został żółty kurz", „na pamięć znam miasta rytm i świt kamienny [...] najbardziej tu nie ma cię, kiedy wstaje dzień", "tęsknię do ciebie z Kępy") ${ }^{28}$. Afektywny miejski dykcjonarz rozpisuje także Wojciech Młynarski, nie tylko umieszczając miłosny idiom w tytułach piosenek (np. Polska miłość, Nie mam jasności w temacie Marioli) ${ }^{29}$, lecz szkicując uczuciowe niuanse in concreto. Mamy tedy rysującą się codzienność („,pod płotem spać, na wiarę żyć, na dworcu piwo z tobą pić - polska miłość") oraz zaklinaną baśniowo niecodzienność (,JJak ona mówi: «Wiej ze mną do Tłuszcza!», to serio mówi czy podpuszcza? Jak mówi: «Porwij mnie choć do Kobyłki!», poważnie mówi czy dla zmyłki?"), nostalgię uprzestrzennianą (,truskawki w Milanówku, tamten ganeczek w dzikim winie [...] i ten przechodzień - spacerowicz [...] wuj konkubinę miał w Brwinowie") i zaadresowaną melancholię (,Jurata '34 [...] na molo żarty i konkury, wędrówki do Jastrzębiej Góry i ta z Jastarni wieść jak grom, że otwarł się Zdrojowy Dom [...] czemuż zły los by miał się karmić młodością mknącą po Jastarni") ${ }^{30}$.

Miasto u Przybory, Osieckiej i Młynarskiego nie tylko bywa wplecione $\mathrm{w}$ historię, intrygę czy anegdotę, pogłębione semantycznie imieniem, refleksem przeszłości bądź emocją (np. nadzieją - „idę cienistą stroną ulicy, a ty słoneczną" - jak u Przybory, zmęczeniem - „zmęczyło mnie miasto żelazne, kamienne [...] i domy olbrzymy klękają, i śpią jak wielbłądy znużone wędrówką, i domy też sny swoje mają" - jak u Osieckiej, zachwytem - „światowe życie [...] sweter z CDT-u, metka z PKO [...] i jak z Broadwayu pro-

\footnotetext{
27 Kolejno cyt. za: J. Przybora, Portugalczyk Osculati, MF, s. 269; tegoż, Pod twoim oknem co nocy stoję, PPW, s. 81; tegoż, Pani Monika, PPW, s. 102; tegoż, To było tak, PPW, s. 119; tegoż, Pieśń o lecie, PPW, s. 71.

${ }^{28}$ Kolejno cyt. za: A. Osiecka, Małgośka, NW, s. 95; tejże, Pożegnanie z Moskwa, NW, s. 312; tejże, Miłość w Portofino, NW, s. 485; tejże, Ulice wielkich miast, NW, s. 572-573; tejże, List z 18.05.1964. (do J. Przybory), L, s. 41.

29 Zob. W. Młynarski, Polska miłość, RS, s. 11; tegoż, Nie mam jasności w temacie Marioli, MUD, s. 84 .

30 Kolejno cyt. za: W. Młynarski, Polska miłość, RS, s. 12; tegoż, Nie mam jasności w temacie Marioli, MUD, s. 84; tegoż, Truskawki w Milanówku, MUD, s. 155; tegoż, Jurata '34 - '38, MUD, s. 187.
} 
gram - Warsaw by Night!" - jak u Młynarskiego) ${ }^{31}$, lecz nade wszystko tchnie zmysłowością, niezależnie od statusu osadniczego, gdyż tutaj równe prawa mają i stolice, i partykularze. Przestrzeń miasta jawi się "otchłanią zmysłów”, jak wyrozumiale napomina Młynarski pewnego „Wertera z Sochaczewa”... Zurbanizowana rzeczywistość wraz z poetyckim indygenatem rozbrzmiewa (Przybora: „tam, gdy z radia płynął walczyk [...] za tobą szedł tylko szept słów jak liści: «nie uiścił»", „przycichły ulice bez dzieci”, "dokoła szumi swym niepokojem twoja dzielnica [...] więc ty nie słyszysz canzony cichej", „aż huczy pianino", „rojne kawiarnie” 32 ; Osiecka: „cóż, że brzęknął ktoś gitarą", "klaksonów gra [...] ciszę tych godzin złych”, „napisy krzyczące [...] i turkot, zgiełk rozmów [...] kamienne milczenie zawisło nad miastem" ${ }^{33}$; Młynarski: „szum i gwar [...] gwiazd estrady śpiewa chór”, „w ustach jej słowo «Kobyłka» to otchłań zmysłów, a nie zmyłka!", "te interludia na pianinie [...] ale pamiętam furtki skrzyp [...] przez chwilę człek nie podejrzewał, że to nie Lorelei w mgle śpiewa, lecz gwiżdże EKD”, "oczka nieduże i w gębie żużel, łykną i bluzną: "Niedobre!»" ${ }^{4}$ ), frapuje wonią (Przybora: "czas pachnieć lipowym alejom!", „pachnie bez - tyle jest do wąchania, że ten zapach nas z domów wygania”; Osiecka: „pachniała Saska Kępa szalonym, zielonym bzem [...] już palą chwasty w sadach i pachnie zielony dym", „a wtem chryzantemy białocytrynowe i wiejskie dzieciaki, zapach pól i brwi płowe”; Młynarski: „w krąg przemysławki europejski zapach czujesz" ${ }^{35}$ ), folguje kubkom smakowym (Młynarski: „porcję leniwych zjadam - à la fourchette - i syty, i szczęśliwy czuję się wnet”, "lecz oprócz znaczeń jest słów smak”, „pomnę, jak strasznie smakowały mi: truskawki w Milanówku, cukier jak śnieg Kilimandżaro”, „na wargach słony wiatru smak”36), epatuje dotykiem

31 Kolejno cyt. za: J. Przybora, Idę cienista strona ulicy, PPW, s. 460; A. Osiecka, Zmęczyło mnie miasto, NW, s. 600; W. Młynarski, Światowe życie, MUD, s. 50.

32 Kolejno cyt. za: J. Przybora, Portugalczyk Osculati, MF, s. 269; tegoż, Pieśń o lecie, PPW, s. 71; tegoż, Pod twoim oknem co nocy stoję, PPW, s. 80; tegoż, Pani Monika, PPW, s. 102; tegoż, Idę cienista strona ulicy, PPW, s. 461.

33 Kolejno cyt. za: A. Osiecka, Pożegnanie z Moskwa, NW, s. 312; tejże, Ulice wielkich miast, NW, s. 572-573; tejże, Zmęczyło mnie miasto, NW, s. 600.

34 Kolejno cyt. za: W. Młynarski, Światowe życie, MUD, s. 50; tegoż, Nie mam jasności w temacie Marioli, MUD, s. 84; tegoż, Truskawki w Milanówku, MUD, s. 155; tegoż, Alkoholicy z mojej dzielnicy, MUD, s. 221.

35 Kolejno cyt. za: J. Przybora, Pieśń o lecie, PPW, s. 71; tegoż, Dzionek zgast, PPW, s. 177; A. Osiecka, Małgośka, NW, s. 95-96; tejże, Zmęczyło mnie miasto, NW, s. 600; W. Młynarski, Światowe życie, MUD, s. 50.

36 Kolejno cyt. za: W. Młynarski, Światowe życie, MUD, s. 50; tegoż, Nie mam jasności w temacie Marioli, MUD, s. 84; tegoż, Truskawki w Milanówku, MUD, s. 155; tegoż, Jurata '34 - '38, MUD, s. 187. 
(np. „dziewczęcych ust kielichy w parkach” - u Przybory, „na słynnej, mokrej, męskiej trasie Sopot - Puck", ,jak ona mówi: «Wiej ze mną do Tłuszcza!», to wiej - złap mocno i nie puszczaj" - u Młynarskiego ${ }^{37}$ ), wreszcie zaspokaja apetyt wizualny (Przybora: „a w twoim oknie - na tle firanki - widzę twój profil i mój zły los", „,barwne po twojej stronie wystawy [...] lepiej z cienistej strony ulicy widać słoneczną"; Osiecka: „widziałam biały ślub, idą święta”, „Sekwana oczy ma piwne”; Młynarski: „Jurata '34 - wdzięk czarno-białych zdjęć", „droga wyszła całkiem prosta, tylko wyboista trochę" ${ }^{38}$ ) lub potrzebę łaknienia (u Przybory: „wciąż piwa krtań wzywa mężczyzny”, u Młynarskiego: "a oni głucho i wargą suchą mówią: «Zabrakło na całą!»" 39). Synestezyjność stanowi bodaj oczywistą rację bytu miasta u całej trójki poetów piosenki, a poniekąd też i klucz do wejścia w tę przestrzeń. Najwidoczniej atoli dają znać o sobie jeszcze inne zmysły, nobilitujące urbanistykę miejscowości imaginacyjnie, albowiem wpisujące realne miasta i miasteczka w kod porozumiewawczy, w domenę wtajemniczenia, a mianowicie zmysły: zdrowego rozsądku, obserwacji, smaku, inteligencji, skrótu, humoru, nadto umowności i „wytwornego żartu od niechcenia”.

Spacer śladem miejskiej uczuciowości, emocjonalności i zmysłowości uświadamia nam - dzięki niezrównanym causerom-narratorom - jednostkowość, wyjątkowość, oryginalność oraz indywidualność miejskiego pejzażu, obdarzonego czułym spojrzeniem człowieka myślącego.

\section{Spacer 3. Śladem autentyzmu}

Wzmiankowana przed momentem oryginalność nie tylko jest pochodną szczególnej perspektywy widzenia bądź nieobojętnego stosunku zamieszkiwanego i zamieszkującego, ewokującego czyjeś doświadczenie w danym miejscu, ale także prawdziwym depozytem pamięci i autentyzmu. Twórczość naszych poetów piosenki, zwłaszcza jej urbanistyczna odsłona, każe niekiedy zajrzeć pod kurdyban współczesnej fasady miasta, poddać egzegezie i refleksji historyczny palimpsest. Jeremi Przybora troskliwie odwiedza facjatki na

\footnotetext{
37 Kolejno cyt. za: J. Przybora, Dzionek zgast, PPW, s. 176; W. Młynarski, Maraton Sopot - Puck, RS, s. 97; tegoż, Nie mam jasności w temacie Marioli, MUD, s. 84.

38 Kolejno cyt. za: J. Przybora, Pod twoim oknem co nocy stoję, PPW, s. 80; tegoż, Idę cienista stronq ulicy, PPW, s. 461; A. Osiecka, Małgośka, NW, s. 96; tejże, Cudowna chwilka, WŚ, t. 1, s. 19; W. Młynarski, Jurata '34 - '38, MUD, s. 187; tegoż, Przyjdzie walec i wyrówna, MUD, s. 29.

39 Kolejno cyt. za: J. Przybora, Pieśń o lecie, PPW, s. 71; W. Młynarski, Alkoholicy z mojej dzielnicy, MUD, s. 221.
} 
warszawskiej Starówce (Jak niegdyś, znów dzisiaj...) ${ }^{40}$. Agnieszka Osiecka wtóruje krokom warszawskich dziewczyn, które wróciły do miasta, na Nowy Świat, Krakowskie Przedmieście, Rynek, Freta, do fryzjera, kina, Harendy czy Fukiera, po tym, "gdy na niebie zabrakło gwiazd [...] gdy nie było Warszawy wśród miast", sporządzając finezyjny bilans obecności - nieobecności, czasem kładąc na jednej szali żal kobiecy (,nikomu nie żal pięknych kobiet"), na drugiej zaś - żal miejski („tak wam żal gazowych latarenek [...] stateczków pływających do Młocin po Wiśle we mgle [...] niemodnych cukierenek [...] ulicznych muzykantów, co Chmielną się snują co dzień [...] chłopaków z Czerniakowskiej, gołębi z Marszałkowskiej"), dumając nad dynamiką przemian („Chmielnej ma nie być już” - cóż więc począć z jakże obeznanym adresem „w podwórku - trzecie piętro, dzwonić"?), uwieczniając rudery i koślawe domki (których lada chwila zabraknie), dawną knajpę „Sielanka” i jej szemraną klientelę, przywołując w pamięci „miasteczko wyrzeźbione z ratuszem oraz rzeczką [...] choć miasto gospodarczo się nie liczy, też pamiętam je dokładniej od Poznania", poszukując "czerwonych maków na Entej ulicy" ${ }^{41}$. Wojciech Młynarski daje semiotyczny prymat truskawkom z Milanówka (a nie kalarepie z Wołomina, "która stanowi czasu znak"), bywalcom praskich i bródnowskich lokali - Heniowi Szramce i tak zwanemu Krzywemu Lesiowi, tudzież jegomościowi spod zakopiańskiego kina „Giewont” - czyli Zdzisiowi („,i wszystko było jak przed laty - zgarbiony kark i dłoni ruch, beret naleśnik, szalik w kratę, to samo oko, ten sam chuch") i pewnemu zaginionemu („dziecko, blondyn, Jan Bobola, zamieszkały - bliska Wola, Sienna dziewięć i po schodkach w lewo z bramy"), wcielając się równocześnie w rolę odpowiedzialnego i empatycznego przewodnika-kronikarza narodowych zawirowań odciśniętych w krajobrazie miasta („tych miasteczek nie ma, nie [...] zapomniany świat i płynie, płynie $\mathrm{w}$ dal" - w piosence Tak jak malowat pan Chagall, "groby powstańców wszędzie są, tam nas, uliczko, prowadź, daleko od tych, co się żrą jak święto to świętować - w utworze Na pięćdziesiąta rocznice powstania warszawskiego ${ }^{42}$. Pieczą nad dowodem osobistym środowiska zurbanizowanego - nie deranżując się zbytnio technokratycznym wymogiem intratności ani dezynwolturą zaszytą buńczucznie w decyzjach miejskich urzędników i włodarzy - Przybora, Osiecka i Mły-

\footnotetext{
40 J. Przybora, Jak niegdyś, znów dzisiaj..., MF, s. 27.

41 Kolejno cyt. za: A. Osiecka, Warszawskie dziewczyny, NW, s. 30; tejże, Nikomu nie żal pięknych kobiet, NW, s. 519-520; tejże, Ballada o Chmielnej, WŚ, t. 2, s. 19; tejże, Grób nieznanego inteligenta, WŚ, t. 2, s. 96; tejże, Czerwone maki na Entej ulicy, S, s. 82.

42 Kolejno cyt. za: W. Młynarski, Truskawki w Milanówku, MUD, s. 155; tegoż, Zdzisio po latach, MUD, s. 69; tegoż, Komunikat o zaginionym, MUD, s. 32; tegoż, Tak jak malował pan Chagall, MUD, s. 156; tegoż, Na pięćdziesiata rocznicę powstania warszawskiego, MPIP, s. 94.
} 
narski wytyczają esencjonalnie kierunki Heideggerowskiego „budowania mieszkania - myślenia" czy - aby posłużyć się organizacyjno-administracyjną przenośnią - uszlachetniają studium uwarunkowań i kierunków przestrzennego zagospodarowania.

\section{Spacer 4. W poszukiwaniu miasta jako metafory}

Narracja miejska w twórczości piosenkowej trójki autorów staje się asumptem do projekcji własnych zapatrywań, mnemotechnicznym raptularzem, zapisaną przestrzenią przenośną, uwierzytelniającą bądź antycypującą oczekiwania. Zmysłowo-obyczajowa urbanistyka często pełni funkcję dialektycznego układu współrzędnych, w którym oś dookolnej, powszedniej, rutynowej rzeczywistości wraz z osią spodziewanej możliwości, migoczącego horyzontu potencjalności, konotującej ambicje i aspiracje, zaniechania lub zamiary, umiejscawia wyobraźnię i pamięć (nierzadko w trybie plusquamperfectum), rejestrując rozdźwięk między codzienną ontyką a świąteczną ontologią.

Legendarnym światem jawi się zrazu przaśna niedaleka miejscowość („,i wziąć zwiać do Wołomina" - u Przybory ${ }^{43}$ ) względem podupadającej gminy, następnie - jak u Osieckiej - Warszawa wobec np. Koluszek (uprzestrzenniona rozpiętość egzystencjalna między nimi zdradza punkt wyjścia oraz obietnicę podniesienia standardu życia), podobnie Paryż w stosunku do Kutna, Paryże i "Szanghaje” w odniesieniu do PRL-owskiej prozy szarego miasta środkowoeuropejskiego (Paryż eksploatowany bywa niczym zapowiedź alternatywnego scenariusza czy odmiany losu: „w zmyślonych Paryżach mnie zgub", domena wspomnień: "tam światła na Pigalle, a tutaj sina dal [...] tam świt nad Saint Lazare, tu noc i pusty bar [...] modry Paryż z tamtych lat" $\left.{ }^{\prime 4}\right)$, Paryż i „w San Francisco złoty most” symbolizują największe skarby świata, które warte są „nocy z Renatą”, a Los Angeles z Hollywood czy Mediolan z La Scalą ekspediują imaginacyjnie w lepszy, znany zazwyczaj pośrednio, wariant rzeczywistości, obrazowany także przez „siódmy Rzym i Krym” (gdzie indziej: „w byle Krym, w byle Rzym”), Londyn („zwłaszcza gdy do Rabki prowadzisz nas") ${ }^{45}$, Toledo z białymi hacjendami. Notabene

\footnotetext{
43 J. Przybora, Taka gmina, PPW, s. 344.

44 Kolejno cyt. za: A. Osiecka, Zesłowiczenie, NW, s. 117; tejże, Byt sobie taki czas..., NW, s. $272-273$.

45 Kolejno cyt. za: A. Osiecka, Noc z Renatq, NW, s. 522; tejże, Gdybym miotła, NW, s. 279; tejże, Sztuczny miód, S, s. 42; tejże, Zabierz kobiete, NW, s. 593.
} 
tożsamą synekdochiczną parabolą życiowej promesy raczy nas Młynarski: „uciekła hen, gdzie Rzym, gdzie Krym”46. Jednoczesna wzmianka o zapomnianej (bądź nieobecnej nawet $\mathrm{w}$ dyskursie regionalnym) peryferyjnej miejscowości i o rozpoznawalnej (czasem wręcz umitycznionej) metropolii stanowi zręczną i lakoniczną peryfrazę ludzkiej ekumeny - w trybie "od - do"; mamy tedy biegunowo dopełniające się Racibórz i Hongkong, Cheetaway i Syracuse, Zakroczym i Warszawę, Nową Hutę i Paryż z Nowym Jorkiem, Wólkę i Paryż, Kalwarię i Londyn (tutaj w wymiarze społecznym: „tych z Kalwarii, tych z Londynu" ${ }^{47}$ ) - u Osieckiej, Nieszawę i Warszawę, Hel i Niceę - u Młynarskiego.

Aliści miasto okazuje się również pamięciowo-wyobrażeniowym kartogramem anamorficznym, wyodrębniającym lub uwypuklającym $\mathrm{w}$ przekazie poetyckim miejsca nieobojętnej historii osobistej, więc - kosztem zaburzenia obiektywnych fizycznych odległości i administracyjnego znaczenia - selektywnie odwzorowującym, a niekiedy wzbogacającym realia. U Jeremiego Przybory Kutno i Grudziądz są metaforycznymi stacjami końcowymi dla płomiennego uczucia („O Kutno! Okrutne Kutenko! - odjęłoś mi miłość jak ręką"), Portofino - spacjalnym emblematem romantycznych uniesień, peron - swoistym pożegnaniem („odjadę $\mathrm{z}$ tego peronu w jesienny, chłodny świat [...] czas trochę będzie się dłużył, choć wkoło piękna wieś"), ulica przebudzeń zaś - rozczarowaniem („od ciebie szłam ulicą przebudzeń, od ciebie szłam bez łez i bez złudzeń") ${ }^{48}$. U Agnieszki Osieckiej miejska mapa memuarystyczna uwzględnia chociażby most w Białobrzegach (gdzie „zostawiłam moje szczęście”), izdebkę na Hożej, a tuż obok - trasę pieszej wycieczki pod Olsztynem, Portofino jako miejsce powzięcia decyzji (,pomarańczowy księżyc płynął, gdy w Portofino mówiłam: nie"), Santa Fe - „to miasto jest jak płomień" - sprowadzone toponimicznie do trzech znamiennych ulic: rue de Hasard (,a podły to był bar"), rue d'Obsession i rue de Question, wspominane uprzednio już „miasto żelazne, kamienne, domami ciężarne, piętrami brzemienne" jako urbanistyczne pendant samopoczucia, nastroju, kondycji człowieka, przeobrażające się w miasto „w którym się spotkamy" i "gdzie się rozstaniemy" - zlokalizowane świadectwo "nagłej rozłąki dwojga serc”, dalej odwiedzamy „zajęczym tropem” Kalisz, Pcim, Końsk, Płońsk, Radom, Konin, Żnin, ponadto rzymski bar (,już za chwilę zaśnie bar, ten dom zagubionych par") i warszawski dach, gdzie „siedzieliśmy jak

\footnotetext{
46 W. Młynarski, Ballada o malinach, MUD, s. 32.

47 A. Osiecka, Piosenka o podziale świata, WŚ, t. 2, s. 182.

48 Kolejno cyt. za: J. Przybora, O Kutno!, PPW, s. 233; tegoż, Odjade z tego peronu, PPW, s. 274-275; tegoż, Droga do Ciebie, PPW, s. 94.
} 
w kinie", komin, rynsztok, cedet ${ }^{49}$. U Wojciecha Młynarskiego stołeczny Pałac Kultury i Nauki ulega metamorfozie w paryski Łuk Triumfalny, a zwrotnie - „dimanche à Orly” w "niedzielę na Głównym”, po sąsiedzku zaś „mały balkon nasturcja porasta i trzepocze na wietrze firanka, świecą zmierzchem w ciemnej ścianie miasta naszych matek maleńkie mieszkanka", w pobliżu sytuuje się tymczasowe Objazdowe Smutne Miasteczko (choć „miasteczko nie pojechało, lecz zostało i się rozrosło!"), sieć osadniczą uzupełnia Kopenhaga (,i raz jest mglista, raz promienna śliczna zimowa Kopenhaga [...] całe nasze życie jest miasteczkiem Pana Andersena”), Jurata („na wydmie sosna karłowata, a pod nią my i rekord świata") - niczym boginka morska, co durzyła się „w prostym rybaku z Chałup czy z Helu”, dwie szkoły: falenicka i otwocka, choć znalazło się też miasto ,jakich tysiące, wokół preria i skały naprzeciw... [gdzie - dop. M.M.] na jednego mieszkańca - jeden szeryf przypadał”, tudzież "mała poczta w małym mieście i na poczcie mała przerwa” oraz „najweselsza stacja w PRL... twoja mała Radość”, do jakiej bieży „drżący od emocji środek lokomocji" ${ }^{50}$.

Powyższe wyznania zdeponowane przestrzennie w parkach, ulicach, knajpach, studniach, dworcach, pomnikach, pocztach, kinach, kwiaciarniach, skwerach, mostach, rynkach, ruinach, podwórkach, bramach, kamienicach, izdebkach, kominach, neonach, dachach, strychach, budkach, kapliczkach i maglach, przystankach i świetlicach, pociągach i tramwajach, rynsztokach i brukach, trzepakach i teatrach - po pierwsze metaforycznie reorganizują miasto, po drugie współtworzą narracje, opowieści, legendy i mikrohistorie, po trzecie grają rolę kodu i kontekstu interpretacyjnego, po czwarte składają się na język miasta, transponując realną materialność w wartości duchowe.

\section{Spacer 5. Tropem miejskich diagnoz i konstatacji}

Przestrzeń miejska potrafi wybrzmieć niczym zarzut bądź postulat, supozycja lub teza, pytanie albo wykrzyknik, kiedy spojrzeć na nią jak na

\footnotetext{
49 Kolejno cyt. za: A. Osiecka, Na moście w Białobrzegach, NW, s. 58; tejże, Miłość w Portofino, NW, s. 484; tejże, To miasto jest jak płomień, NW, s. 566; tejże, Zmęczyło mnie miasto, NW, s. 600; tejże, Dwie szklaneczki wina, NW, s. 9-10; tejże, Zajęczy trop, WŚ, t. 6, s. 203; tejże, Parę pytań, WŚ, t. 9, s. 119; tejże, Siedzieliśmy na dachu (Siedzieliśmy jak w kinie), NW, s. 316.

50 Kolejno cyt. za: W. Młynarski, Bohaterowie Remarque'a, MUD, s. 97; tegoż, Niedziela na Głównym, MUD, s. 55; tegoż, Naszych matek maleńkie mieszkanka, MUD, s. 168; tegoż, Smutne miasteczko, MUD, s. 58; tegoż, Miasteczko Pana Andersena, MUD, s. 183; tegoż, Jurata '34 - '38, MUD, s. 187; tegoż, Ballada o jantarze, RS, s. 49; tegoż, Ballada o Dzikim Zachodzie, MUD, s. 31; tegoż, Ballada o kasjerze, MUD, s. 194; tegoż, Twoja mała Radość, PM, s. 61.
} 
pretekst do zajęcia stanowiska, sformułowania recenzji, wydania diagnozy, podzielenia się konstatacją. Przybora (w mniejszym stopniu), Osiecka i Młynarski wykorzystują narrację osadzoną w środowisku zurbanizowanym, aby uczulić i zaakcentować najczęściej bolączki i niedoskonałości miejskiego laboratorium społeczno-psychologicznego i kulturowo-obyczajowego, permanentnie znajdującego się in statu nascendi. Autorzy na podstawie uważnych i trzeźwych obserwacji dochodzą do konstruktywnych, ironicznych czy sarkastycznych refleksji, portretując dynamikę, stereotypy, beznadzieję i głupotę.

Otóż, doświadczenie uczy, iż "to nie jest rzecz prosta - z Łazienkami na wiosnę się rozstać” (Przybora), atoli nie rozstrzyga, "co dalej, szary mężczyzno, gdy należą do pań [...] i Krakowskie, i MDM. I miasto, i wieś, i forma, i treść” (Osiecka), chociaż „przedwczoraj po południu Zielna róg Szóstego Grudnia rzeczywistość przeszła me oczekiwania" (Młynarski) ${ }^{51}$. Ostatni z cytowanych zarówno surowo diagnozuje proweniencję współczesnych mieszkańców stolicy („,ta Warszawa, fakt widoczny, nabzdyczona jest i tłoczna, lecz prawdziwych warszawiaków to w niej nie ma”, „w mieście szarym chamską, napływową stonką"), jak bezlitośnie smaga i piętnuje jakość społeczności miasta („zwiedzam stare komysze i zadumany stoję, wołam - echa nie słyszę, wszystko jakieś nie moje [...] strasznie trudno w Śródmieściu spotkać inteligenta"), do mentalnej i moralnej deprecjacji której przyczyniła się już to niefrasobliwość pamięci zbiorowej („na Generała Zajączka, na Solcu, na Gwiaździstej, gdzie wrosła szara bolączka w nieludzki, wredny system, na żadnej, smutnej ulicy - wciąż w szarosinym kolorze - nikt nie wmuruje tablicy, że tutaj żył i tworzył”, "tych miasteczek nie ma już, pokrył niepamięci kurz te uliczki"), już to upadek życia kulturalnego (,teatr kona, a tak niedawnymi czasy śmiać się tutaj przyjeżdżano z całej Polski" - o teatrze "Rozmaitości”, „,i nie bardzo jest gdzie pójść, bo nie ma Dudka”, „,nie ma gdzie pójść, nocą straszy schabowy i seta, gdzie jest ten wdzięk, gdzie są Szpaki, Dudki, Owce?", za to tandeta króluje na opolskiej estradzie amfiteatru, za co zresztą Młynarski dał wykonawcom „żółtą kartkę") $)^{52}$. Zasadnie wtóruje tym utyskiwaniom Osiecka, dopełniając goryczy miejskiego landszaftu: "szara Wisła w dole śpi", "na pamięć znam miasta rytm i świt kamienny", szare ulice, szare balkony, szare kominy - "gdzieniegdzie jeszcze kocie łby", „miasto,

51 Kolejno cyt. za: J. Przybora, Profesor Pęduszko i Wiosna, MF, s. 26; A. Osiecka, I co dalej, szary mężczyzno?, NW, s. 444; W. Młynarski, Rzeczywistość, MPIP, s. 26.

52 Kolejno cyt. za: W. Młynarski, Od dziś w "Expressie”, MPIP, s. 87; tegoż, Dudek, MPIP, s. 82; tegoż, Powrót do Śródmieścia, MUD, s. 167; tegoż, Amerykańska kurtka wojskowa, MUD, s. 70; tegoż, Tak jak malowat pan Chagall, MUD, s. 156; tegoż, Ratujmy "Rozmaitości”, MPIP, s. 66; tegoż, Dudek, MPIP, s. 82; tegoż, Nie ma gdzie pójść, RS, s. 81; tegoż, Żótta kartka, MPIP, s. 59. 
które zna, jak brudną plamę" - mimo blasku ekranów, by na antypodach wyobraźni obiecać światełko w tunelu: „w tych Paryżach całkiem możliwie jest”, "ulica japońskiej wiśni niech ci się przyśni co jakiś czas" 53 .

Nasi poeci piosenki z czułością, rozrzewnieniem i frasunkiem pochylają się nad jakże przez nich oswojoną przestrzenią, z którą zadzierzgnęli uczuciową, zmysłową, a bodaj metaboliczną relację, po części uzależniając się od stanu zachowania i jakości funkcjonowania tych miejsc. W czym czytelnicy ich twórczości (i miasta) są im podobni. Dlatego też, niewykluczone, skargi - dobitne $\mathrm{w}$ treści i subtelne $\mathrm{w}$ formie - pozostają zrozumiałe i mogą być słyszalne w polifonii współczesnej opinii publicznej.

\section{Spacer 6. W stronę przestrzeni wyobraźni}

Poeci piosenki zabierają czytelnika w podróż również po terytoriach powołanych do życia twórczą fantazją, wytyczonych wyobraźnią, sublimujących - przestrzenną hiperbolą, wynegocjowaną z obiektywnym światem metonimią czy symptomatyczną interpolacją - dotychczasowe doświadczenie. Na mapie osadniczej pojawiają się zatem miejsca nieprzypadkowo nazwane, ponieważ ich imię natychmiast odsyła do nieindyferentnej fabuły (np. knajpa „Pod Knotem”, kawiarenka „Sułtan”, knajpka „U Honoraty”, gdzie „ojciec i syn mknął do składziku jej win" ${ }^{44}$, bar "Smok" z Listu do jedzącej Eurydyki, restauracja "Złota Kakadu” - u Przybory, lokal „Pod Poziomką" - u Osieckiej, bar "Smakosz" - u Młynarskiego), umityczniając nawet realne ekwiwalenty tychże (jeśli takowe istnieją).

Autorzy lokują w stacjach, ulicach czy instytucjach własne tęsknoty i pretensje, obserwacje i sądy, przypisując im niekiedy rangę miejsc progowych, rozstrzygających lub pointujących pewne zjawiska i procesy, podwyższając niechybnie ich status semiotyczny, jak to się dzieje w przypadku Stacyjki Zdrój („wciąż wracam na stacyjkę białą pociągiem, który lato wiózł” 55); Entej ulicy (gdzie zakwitają czerwone maki) i ulicy japońskiej wiśni (jako baśniowej alternatywy szarej egzystencji w PRL-u); ulicy Nowoprojektowanej (mieszkanie numer 1410 - „nie bardzo podły adres” ${ }^{56}$ ), Miasta Niekochanych

\footnotetext{
53 Kolejno cyt. za: A. Osiecka, Tańcz Warszawo, śnij Warszawo, WŚ, t. 8, s. 199; tejże, Ulice wielkich miast, NW, s. 572; tejże, Ulica japońskiej wiśni, WŚ, t. 3, s. 182; tejże, Najpiękniejsza (Biały welon), WŚ, t. 4, s. 106; tejże, Jak na Paryż, WŚ, t. 2, s. 113; Ulica japońskiej wiśni, WŚ, t. 3, s. 182.

54 J. Przybora, U Honoraty, PPW, s. 479.

55 J. Przybora, Stacyjka Zdrój, KSP2, s. 141.

56 W. Młynarski, Kolęda nowoprojektowana, WCB, s. 82.
} 
(gdzie "nie ufaj tramwajom - zawsze zatłoczone, zawsze się spóźniają [...] ludzie źli i smutni, nie podadzą ręki i rwą się do kłótni") i Miasta Zakochanych (gdzie "łże bezczelna władza, ale to nas śmieszy, nam to nie przeszkadza”), skąd podejmujemy przechadzkę tam, gdzie "za siedmioma górami piękne miasto wznosiło swe mury", dobrodusznie omijając szerokim łukiem niejaki Wydział Bezprawia, Katedrę Chamstwa czy Samodzielny Zakład Cynizmu na pobliskim uniwersytecie ${ }^{57}$ (odpowiednio - u Przybory, Osieckiej, Młynarskiego.

Ale przecie doskonale znamy te miejsca $\mathrm{z}$ autopsji... To cóż, że starannie ukryte za niedopowiedzeniem, schowane w niedosłowności czy finezyjnej aluzji. Niby tekst miasta się rozszerza, kolonizując coraz to nowe regiony podyktowane wyobraźnią, kulminujące semantyczne kompromisy na rzecz jędrności i miąższości przekazu, lecz gwoli prawdy to przyglądamy się - niechaj nawet w sztafażu metafory, diagnozy czy elipsy - dobrze rozpoznanym, znajomym, ba - swojskim fragmentom przestrzeni. Dyskretną umowność urbanistyki imaginacyjnej nasi poeci piosenki szczepią przeważnie $\mathrm{w}$ realnej glebie. I może właśnie dzięki temu ich wyobraźnia wydaje się nieokiełznana - pozostając czytelną.

\section{Spacer 7. Na szlaku miejskich idiomów}

„Ja pana z sobą zabiorę w nieznaną podróż daleką [...] pomkniemy trasą przecudną widoków, przygód i zjawisk" 58 - jak zachęca piosenka Jeremiego Przybory, który wraz z Agnieszką Osiecką i Wojciechem Młynarskim mości nam rzeczywistość miejską, niwelując niedogodności i powszednie krenelaże, urządzając przytulnie kontekst codziennej wędrówki, wydobywając na jaw to, co w zabieganiu jesteśmy skłonni przeoczyć. Autorzy piosenkową mową wiązaną podejmują się trudnej - acz przynoszącej sporo satysfakcji - roli translatorów dyskursu przestrzennego na język człowieka. Stosunkowo często udaje im się uchwycić nieprzetłumaczalne, obdarzyć czytelnika (słuchacza, widza) idiomem miejscowym lub społecznym. Paralelnie tę kwestię ujmując, oferują tedy jakość nie do podrobienia, formę źródłową, niczym architekt wymyślający dla miasta oryginalną budowlę, która w sposób naturalny i oczywisty je zdefiniuje, ogniskując lokalną tradycję, niemniej przeto będąc zrozumiałą uniwersalnie. Idiom bowiem wyodrębnia

57 Kolejno cyt. za: W. Młynarski, Dwa miasta, MUD, s. 80; tegoż, Ballada o szczurach, JWZ, s. 15; tegoż, Wydziat Bezprawia, RoS, s. 180.

58 J. Przybora, Ja pana w podróż zabiorę, PPW, s. 264. 
cechę charakterystyczną, aliści nie w kategoriach statystycznych, lecz fenomenologicznych.

Idiom to celna kwintesencja momento-punktu, chciałoby się rzec. Któż z nas zatem nie szedł "ulicą przebudzen", ,cienistą stroną ulicy" (skąd lepiej „widać słoneczną"), nie snuł się po średnich miastach, "gdzie żaden dom nad inne nie wyrasta [...] [gdzie - dop. M.M.] nie szarpiesz się, nie szastasz", nie otwierał okna "na tę moją samotność", nie szukał drobnych pań z ogromnym mieszkaniem, co „na którymkolwiek piętrze rozwiążą nieraz wnętrze że klękaj ty i klęcz na widok takich wnętrz", nie śnił o współmieszkańcach, współpasażerach, którzy „luźnym zdążają tramwajem, wytworną konfekcją okryci, i darzą uśmiechem się wzajem, i wszyscy do czysta wymyci" (Przybora ${ }^{59}$... Któż z nas nie przebywał ongiś „w tym mieście, w którym się spotkamy" („[...] wtem zatrzymają się zegary i wszystko będzie jak we śnie") oraz „w tym mieście, gdzie się rozstaniemy” („[...] nic się nie stanie, nic nie zmieni") - konotujących amplitudę namiętności i losu, podobnie jak "plac przypadków”, "plac pomyłek" i "plac powrotów” - albo - „rue de Hasard”, „rue d'Obsession” i „rue de Question”, nie wierzył, że gdzieś „zajeżdża tramwaj nadziei niewinnej i na ten tramwaj ktoś czeka" (Osiecka) ${ }^{60} . .$. Któż z nas wreszcie nie utożsamiał poniewczasie Miasta Niekochanych z Miastem Zakochanych, nie siedział „na murku jak ptaszki” (Młynarski) ${ }^{61} \ldots$

Poruszając się po mieście patrzymy na nie frazami piosenek, tak trafnie wszakże przylega optyka Przybory, Osieckiej czy Młynarskiego do rzeczywistości zurbanizowanej. Boć i zabierają nas w podróż ci autorzy, niebanalni przewodnicy i niesztampowi opowiadacze, uśmiechając się znacząco do naszej inteligencji i smaku.

Przesłanką do snucia powyższych rozważań był pomysł odszukania motywów związanych z szeroko pojmowanym miastem w poetyckiej twórczości piosenkowej trojga autorów. Niechaj czytelnik okaże się łaskaw potraktować niniejszy tekst jako jedynie glosę, utrzymaną w tonie adnotacji czy didaskaliów na marginesie dzieła, jakim jest dorobek Agnieszki Osieckiej, Wojciecha

59 Kolejno cyt. za: J. Przybora, Średnie miasta, PPW, s. 413; tegoż, O, Romeo!, PPW, s. 137; tegoż, Najmilsze sq drobne panie, KSP2, s. 157; tegoż, Już czas na sen, PPW, s. 282.

60 Kolejno cyt. za: A. Osiecka, Dwie szklaneczki wina, NW, s. 9; tejże, Od pierwszego wejrzenia, NW, s. 529; tejże, To miasto jest jak płomień, NW, s. 566-567; tejże, Tramwajowi ludzie, S, s. 87.

61 Kolejno cyt. za: W. Młynarski, Dwa miasta, MUD, s. 80; tegoż, Alkoholicy z mojej dzielnicy, MUD, s. 221. 
Młynarskiego i Jeremiego Przybory. Kiedy przez „szkiełko i oko” próbuje się zerkać na sztukę, warto sobie przypomnieć słowa autora Terpentyny dziadka Pohla poświęcone autorowi Dziadka Paździerzaka: „Ma wielkie, wspaniałe poczucie humoru i widzę już Jego minę, gdy się poddaje finezyjne małe formy uczonej analizie" 62 . Muza piosenki nie chodzi w koturnach.

\section{Źródła audio}

Młynarski Wojciech, Absolutnie, seria „Złota Kolekcja”, Pomaton EMI, Warszawa (CD) 2000

Młynarski Wojciech, Prawie całość, Polskie Radio SA, Warszawa (CD) 2001

Osiecka Agnieszka, Pięć oceanów. Piosenki 1962-1997, Polskie Radio SA, Warszawa (CD) 1997

Przybora Jeremi, Wasowski Jerzy, Zimy żal. Piosenki z Kabaretu Starszych Panów, nagranie 10-tego Przeglądu Piosenki Aktorskiej Wrocław 1989, Pomaton, Warszawa (CD) 1992

Przybora Jeremi, Wasowski Jerzy, Kabaret Starszych Panów: Piosenka jest dobra na wszystko, Polskie Nagrania Edition Ltd., Warszawa (CD) 1997

Przybora Jeremi, Wasowski Jerzy, Piosenki Kabaretu Starszych Panów, Polskie Radio SA, Warszawa (CD) 2000

Turnau Grzegorz, Cafe Sultan. Piosenki Jeremiego Przybory i Jerzego Wasowskiego, Pomaton EMI, Warszawa (CD) 2004

\section{Sensual and Moral Urban Planning at Post-War Poets-Authors of Song Lyrics (Jeremi Przybora, Agnieszka Osiecka, Wojciech Młynarski)}

Summary

The paper follows the urban motif in works of Jeremi Przybora, Agnieszka Osiecka and Wojciech Młynarski. It proposes an interpretative matrix in the formula of seven passages: (1) following urban morality, (2) following urban senses, feelings and emotions, (3) following authenticity, (4) in search of the city as a metaphor, (5) following urban diagnoses and findings, (6) towards the space of imagination, (7) on the route of urban idioms.

62 W. Młynarski, Nie ma już takich poetów!, w: J. Przybora, Piosenki prawie wszystkie, s. 5. 